\title{
Sexuality and Objectification in Dastan Narratives: Women as Objects of Desire in Hoshruba, the Land and the Tilism (Book 1)
}

\author{
Farrukh Nadeem \\ Lecturer, Department of English, International Islamic University, Islamabad
}

\begin{abstract}
The writers of dastan narratives reflect their age-old contextual desire(s) in fictional experiences. The never-ending popularity of these ideologically romantic tales is significant in the history of Urdu language and literature. Metonymically, the dastan, Tilism-e-Hoshruba, encompasses the much celebrated theme of Dastan-e-Amir Hamza-an eternal battle between virtue and vice-in its narrative discourse, but the quickness of the fantasized actions makes this dastan phantasmagorically more thrilling. Despite being enormous source(s) of narrative pleasure in the Subcontinent, these classical discursive practices prove to be an explicit reflection of the textual and sexual politics traditionally perpetuated in the Indo-Islamic patriarchal structures. The rendition of female characters, for instance, in the narrative discourse of Hoshruba, depends on the patriarchal modes of production and representation pre-existing in classical cultural contexts. Presented as alluring objects of the ideological syntax, many of the women in these fictional texts customarily remain victim to the patriarchal narrative gaze. The narrators of dastan employ an evocatively figurative language in sensationalizing the graphic description of the female characters in Hoshruba. From seductions to submissions, all of their acts are pre-eminently destined to serve the phallogocentric desires of their authors, audience and chivalrous heroes. This paper, therefore, is the critical study of the patterns of desire(s) with reference to sexuality and the culture of objectification in Dastan Hoshruba, the Land and the Tilism, Book 1. ${ }^{1}$ By intersecting romance and sexuality, it also aims at exploring the narrative units of desire that objectify the sexuality of female characters through the mechanics of fantasy and gaze.
\end{abstract}

Keywords: objectification, sexuality, dastan narratives, Ideology, Patriarchy, desire, gaze

\section{Introduction}

The contemporary critical consciousness ${ }^{2}$, in literary and cultural studies, hardly relies on the denotatively conventional meanings of words and texts. To elaborate the thematic content of a word or a phrase in a literary or a fictional text, it - the critical scholarship after poststructuralism-traces the connotative and contextual links between language and power (ideology). With the deconstruction of myths including the aesthetically articulated innocence of the narrative language or the linguistic patterns in different 
fictions, a paradigm shift occurred in the tradition of literary criticism which is still affecting the cultural, Marxist, Postcolonial and Gender studies by foregrounding the politically structured truths or, in other words, the narrative truths of human history. The well-arbitrated words and their respective meanings in a traditionally acknowledged poetic or a narrative art turn out to be ideologically political, and, ultimately, the preoccupation with (specific) meaning has been questioned in the analytical criticism projected after the above-mentioned theoretical approaches. Besides, the structural, narratological and semiotic models introduced and applied in French academia have facilitated the Poststructuralist, Postcolonial, Marxist and Feminist interpretations by highlighting politically and ideologically diverse narrative patterns in different fictional texts. For example, the French semiotician Greimas (1983) discovered a narrative relationship based on three axes (of Knowledge, Desire and Power) in his 'actantial model' which tends to emancipate both the explanation and the interpretation of popular tales from the popular tradition of criticism, impressionism. Following the Greimasean narrative model, Farrukh Nadeem (2017) has further illustrated this triad narrative relationship (Ideology, Desire and Power) in dastan Hoshruba, the Land and the Tilism. Having traversed the narrative kinship between ideology and power in dastan Hoshruba, I intend to examine how, as an age-old discursive practice, the dastan Hoshruba objectifies the female characters for the gratification of the popular public taste in (pre-) British India. The word sexuality, in this kind of study, signifies not only the biological or gendered identity, or masculine or feminine power but also the desire to be embodied as an ideological adjective of comparative and superlative degrees. In the relationship between power and desire (for an object) in our discursive practices, the actively conclusive role of cultural and civilizational ideologies cannot be ruled out because this conclusiveness exploits essentialism in its methods in interpreting literary and fictional texts. Despite some essential variations in their interpretations of cultural texts, the poststructuralist, Marxists and feminists call the nexus between power and patriarchal ideology into question. Since culturally established power structures determine the subjective or objective positions of different characters in a fictional text, there is an urgent need to know and interpret how human language and the art of rhetoric, in the evolution of literary texts, have empowered and eloquently privileged patriarchal structures, particularly in the narrative history of the pre-partition subcontinent.

To be an object of an ideological syntax signifies a passive position in discursive practices of any culture. Literary and fictional texts are written by human beings and for human beings for certain materially dialectical, didactic or aesthetic ends. Through diegetic or mimetic techniques, they narrate, describe, and dramatize human experiences in their supposedly thoughtprovoking thematic contents. However, despite their claims of universality and objectivity in presenting their ideas and human conditions, their narratives prove to be conditioned with some popular sets of belief systems traditionally and institutionally pre-existing in their cultural contexts which cultivate a narrative desire in discursive practices. The desired protagonist is 
the personification of all that is idealized by the common human beings of a culture because he is, as Brooks (1984) illustrates in his essay "Narrative Desire", an embodiment of the ambition that provides not only a typical novelistic theme, but as well as a dominant dynamic of plot: a force that drives the protagonist forward, assuring that no incident or action is final or closed in itself until such a moment as the ends of ambition have been clarified through success or else renunciation. (p. 312)

In his pursuit of the desired objects, according to the collectively demanded dynamics of a popular plot, the protagonist or the missionaccomplishing hero strives his best to meet the expectations of his readers and proves himself, as expected, to be an ideal custodian of his culturally desired values. Endorsing the narrative relationship between the text and its (expected or desired) meanings, he justifies his presence in a popular fictional discourse. About the narrative nexus between a fictional text and the dynamics of ambition (or desire), Brooks (1984) contends:

Ambition provides an armature of plot which the reader recognizes, which indeed constitutes the very readability of the narrative text, what enables the reader to go about the construction of the text's specific meanings. Ambition is inherently totalizing, figuring the self s tendency to appropriation and aggrandizement, moving forward through the encompassment of more, striving to have, to do, and to be more. The ambitious hero stands as a figure of the reader's efforts to construct meaning in ever-larger wholes; to totalize his experience of human existence in time; to grasp past, present, and future in a significant shape. (p. 312)

With reference to the triad relationship of the protagonist, the reader and the context, Brooks' (1984) illustration of the dynamics of heroic desire is much significant. It explains how psychologically and effectively the element of desire works in embedding harmony between a discursive hero and his audience. The popular heroism is a sum total of all ideologically sponsored narrative traditions of a nation or a society. A desire personified and popular self of the protagonist cannot declare itself to be an individual or natural voice; being a culturally articulated self, it has to be faithful to the publicly desired actions. To call a discursive hero a natural product, therefore, is the negation of the desire of his cultural contexts since all what he toils for and what he accomplishes is the desire of his ideological context. Even the act of shedding the blood of his enemies signifies the cherished violence nursed and mastered through the collectively approved physical and emotional practices.

The popular hero, being the product of collective consciousness, cannot risk his ideological position by transgressing the culturally established taboos. In an ideological context, the popular fiction writers hardly afford any transgressive experimentation in their fictional texts, as their projection cannot withstand the institutionalised axioms and beliefs. Their popularity exists in the manifestation of an outright harmony with popular ideological structures. Writers of the fictional texts, like the dastan Hoshruba, the Land and the Tilism, employ the themes, characters, their respective locations, and 
settings according to the popular and ideologically vindicated desires. There is no point in accepting a fictional text at a massive scale unless it (re)presents thematic desire of the public through the consequential sequences of actions and events in its fictionality. Similarly, the choice and chain of characters and their actions prove to be effective provided that they are plotted in accordance with cultural classifications. The female characters in such fantabulous classics, as a matter of fiction, are painted the way they have been culturally classified, identified and structured in a society.

Since women are structured through the culturally endorsed syllabus of gendered taxonomy, they are reflected in the fictional texts as realistically as the rituals of the patriarchal perspective permit. Accordingly, for the gratification of the desires of their readers, they (the writers of popular fictional texts) thoroughly objectify and commodify women folk. Particularly, in popular horror fictions, vampire or ghost stories or fantasies like dastan Hoshruba, the art of female characterization has been synthetically exaggerated. Apparently a fairy tale, the dastan Hoshruba offers an omnipresent battle between virtue and vice, but the subtext of these fantastic narratives unfolds the political phantasmagorias (of patriarchal desire) working through the entire chains of events and actions.

Historically, an eight-thousand-page epic, dastan Tilism-e Hoshruba, is a sequel and an extended version of a colossal narrative structure called dastan-e-Amir Hamza that marks the romantic and chivalric adventures of Muslim epic heroes in foreign lands. Intertextually, the dastan Hoshruba alludes to the narrative characteristics of Dastan-e Amir Hamza as it has also been codified in accordance with Indo-Islamic contexts. Volume after volume production and re-production of dastan texts, at different stages of Indian History, epitomize the cultural desire for stories - an utmost narrative anxiety. However, neither Dastan-e Amir Hamza nor Hoshruba are what Cavallaro (2007) calls narratives and texts as 'self-contained autonomous experiences' but, like other intertextually embedded texts, "are built from traces and echoes left by other stories and voices" (p. 6o). "To this extent", argues Cavallaro, "any text can be thought of as a tapestry of quotations, a mosaic of allusions" (p. 60 ). With reference to the interpretations of such culturally established texts, Cavallaro elaborates:

If texts are intertextual, subjective (i. e. personal or individual) responses to texts are intersubjective: that is dependent on how each person's interpretation of the world interacts with interpretations proposed by other people within the code and conventions of a community, and it is accordingly endorsed or rejected (p. 6o).

It means that the interpretation of a fictional text depends on the accepted or resisted system of codes and conventions. Obviously, the popularity of a fictional text like dastan owes a lot to the blanket acceptance of its intertextual allusions by the audience, readers and local critics. That is why, while applying a dialectal and analytical reasoning on the politics of its fictionality, there exists a tradition of resistance that discourages the 
contemporary modes of interpretation of metanarratives. Dialectically, it repudiates the indispensable questions on the conventionally synchronized patterns of ideological homogeneity lavishly practiced in popular fictional texts. For the relentless personification of their ideals, the popular tradition essentializes the ideological relationships between words and meanings, texts and their explanations. It is owing to this ossified relationship between texts and signification that other modes of interpretation remain ignored on cultural peripheries. Knowingly, all ideologies are totalitarian in their essence and homogenous in their application (Rush, 1992), and this fact politicises fantasies and fictional texts through fixing the identities lopsidedly. In this context, this research incorporates the ideologically ignored modes of interpretation in evaluating the dastan narratives.

With the historical evolution in subcontinent, the Dastan-e-Amir Hamza, as a popular literary genre, ideologically celebrates ideologically its emergence in its own socio-cultural context. Musharraf Ali Farooqi, the translator of this dastan, writes:

The adventures of Amir Hamza originated in Arabia in the seventh century to commemorate the brave deeds of Prophet Muhammad's uncle, Amir Hamza. In the course of its travels in the Middle East and Central Asia, this story incorporated many local fictions and histories and became an entirely fictitious legend. Then sometime between the eleventh and the fourteenth centuries, The Adventures of Amir Hamza found its way to India. (2009, p. x)

The dastan Tilism-e Hoshruba was published at Nawal Kishore Press in British India between 1893 and 1905. On some thematic and structural patterns, it is different from Dastan-e Amir Hamza, because

Mir Ahmad Ali wanted to make Hoshruba the most sharp-clawed, shiny scaled tale in the whole of the Amir Hamza Cycle, so he liberally poured in vicious sorceresses, nubile trickster girls, powerful wizards, and dreaded monsters and stirred the tale with non-stop action (Farooqi, 2009; Zubrzycki, 2018, p. 84).

Equally important to know is the fact that of all the popular narrative forms written in subcontinent, the dastan Hoshruba stands unique in its discourse, for it has been based on the harmonious blend of Arabic, Persian and Indian cultural norms and practices. It is for this reason that the dastan, as a whole, is considered an accurate projection of Indo-Islamic civilization. Away from European dynamics of desire to occupy, colonize, industrialise, and capitalise on the resources of foreign lands and nations, the Indian cultures would celebrate their narratives at different occasions. Owing to the mesmerising effects of narrative events and actions, the dastangos (story tellers) were invited by Nawabs and noblemen (the land owners) of United India in $19^{\text {th }}$ century to narrate for them the fresh and exuberant episodes of their dastans. Professionally skilled in designing mind-boggling tales, the dastangos would never disappoint the lovers or the consumers of their stories in materializing all that was the taste of agricultural traditions. Thoroughly 
accustomed to the significant characteristics of rituals and romances, they would try their best in making their performance a matchless success. It was also a matter of narrative competence and performance in their cultural traditions which, consequently, ensured them a privileged position not only in the discursive arenas of courts and castles but also at other public festivals.

Primarily the dastan Hoshruba presents an eternal battle between virtuous and vicious cycles operating in the human world. Amir Hamza and the heroes of his camp belong to the former, whereas the arch rivals of this camp, the false god Laqa and the commander of his camp, Afrasiyab, represent the latter. On account of transgressive acts against the True Faith, Amir Hamza and his heroes have declared a decisive crackdown on the dwellers of Hoshruba. Since their subversive acts against the doctrines of True Faith, the sorcerers and sorceresses have invited the wrath of the commanders of Amir's army for practicing false beliefs in their camp, the land of magic and enchantment. Despite their appallingly aggressive acts, some of their women are successful in alluring the commanders and heroes of Amir Hamza camp. Through their disarming rhetoric, the dastangos paint these female characters with ideological colours in order to to subdue, love, and conquer them until they stay helplessly unfortified and eventually embrace the doctrines of the 'True Faith.' The neophyte female characters, by dissociating themselves with sinful life in Hoshruba, embrace the culturally accepted piety and patriarchal powers. For them, getting rid of sins is to be subdued by the ideological will of the chivalrous heroes. Surprisingly and shockingly, the imaginative exuberance of the dastan narratives turn out to be unilaterally ideological because the patriarchal gaze has been politically entwined with a popular desire to gratify the narrative and psychological needs of the audience. The difference between 'the women as ours' and 'the women as others' can be identified with reference to their alliance with the desire of narrative contexts.

Between voiced and unvoiced historical documents, in the tell-tale tradition of dastans, it is the corpus of patriarchal values which is openly voiced. Consequently, the absence of female voice ensures a free play of binaries by the sleight of male hands, the discursive presence. Therefore, written through the masculine ethos, the telling and showing techniques, exploited in the culture of folk tales pre-eminently represent the male plotting of beginnings, middling, climaxing, and endings of stories. Seen through the objectified lens, the dastan texts appear to have organized all choices and chains of linguistic units, eventful corollary, (ideological) causes, and effects with narratively perpetuated effects of masculinity. Thus the phallogocentric reciprocity of gaze is practiced heavily in the narrative discourse of Hoshruba that reflects how, psychologically, the bourgeois tools of production in British India experience an intriguingly scopophiliac obsession with female body. Not surprisingly, the lopsided politics of classical narratives is as omnipresent as the 'popularly' natural truths of the so-called civilized societies from Greek antiquity to contemporary times. No matter how political they were in their contents, the massive popularity of these mega narrative structures, the desireproducing machines, ${ }^{3}$ was based on their ideological services for 
entertainingly traditional values. In her essay "Transforming Superheroes through Female Music Style," Toffoletti (2007) expresses her reservations on the relationship between male legendary characters and female bodies in ancient and modern classics. According to such critical observation, the female bodies, even in modern visual narratives, are hired to gratify male sexual desires (McEniry, M. J. 2106; Toffoletti, 2007). Likewise, the well-known epics of the documented history reflect this cultural politics in their epic gaze which is revisited and critically investigated by Lavott (2013) in her book, The Epic Gaze: Vision, Gender and Narrative in Ancient Epic. Through a historically essentialized relationship between expression and masculinity, the male gaze and female objectification are inherently interdigitated in the epic patriarchal narrative structures, for they were meant, in the past, only for the male (public) taste and sensuousness. Incorporating psychoanalytical frame of reference, Cavallaro illustrates two forms of objectification of women in his essay on human gaze:

Objectification can take two forms and from each a particular stereotype of femininity ensues. On the one hand, women may be devalued, demonized as the quintessential symbol of sexual corruption. Characterized as the overpowering and the vampiric beast to be repressed, the demonic woman fuels male fantasies of containment of female body. This option is connected with sadism. On the other hand, woman may be over-valued as a fetish. This stereotype embodies the male desire to transform the female body into a decontextualized icon to be placed on a pedestal and worshipped from a distance. (p. 137)

Cavallaro's classification of women's objectification signifies the absence of normality in the narrative discourse of male cultural spatiality. If, on the one hand, women are stereotyped as demons and extolled and idealized as goddesses on the other, the state of normality between demonization and idealization is evidently absent. In Hoshruba, the land and the Tilism, there is a categorical difference between women in general, the princesses with utmost beauty, and women with utmost demonic characteristics. But the art of characterization, through fantastic hyperbole, denies a balanced space where womenfolk can exert reason in their narrative activities. It is also owing to this classification of female characters in Hoshruba that this study becomes more relevant in contemporary culture of criticism on dastan narratives.

\section{Rationale and Situatedness of Research}

In human history, there has always been an interdependent relationship between those who produce narratives and those who consume them. The narrators of gratifying tales are the seasoned men of discursive eloquence who transfer cultural knowledge to those who do not know how the desired knowledge is being constructed through stories and how the established narratives construct their positions in different cultural settings. This ideological process involves various methods and techniques of communication and it is, evidently, the human language that facilitates the narrators in producing all that is abstract or concrete, fantastic or realistic, 
sacred or mundane, spiritual or material, elitist or egalitarian, and chauvinist or democratic in everyday human activities or discursive practices. Correspondingly, all cognitive schemas are constituted in human mind through the application of grammatical structures existing in human cultures. The narrative structures are manifestations of the very latent archetypes that, consciously or unconsciously, channelize human activities. There is an endless chain of debates on the politicization of narrative structures but the "fundamental to these discussions," as Strysick (1997) holds in "The End of Community and the Politics of Grammar," is thinking about the very ordering of our relations with one another, which I will call a community, and the ways in which we talk about and communicate that being together. Indeed, the very grammatical or foundational character that underlies the structure of our narratives is in greatest need of our critical attention (p. 196).

Elsewhere, in order to endorse the indispensable kinship between a community and language, Strysick (1997) rightly quotes Nietzsche's words on the politics of language in human evolution: "We are prisoners of a grammar invented at an early stage of human evolution, and it seems that, since we can think only by using language, our reason too is conditioned by the most primitive notions of reality." (p. 196).

Without language, 'the gift of speech bound up with politics' (Joseph, 2006, p.2), human evolution is impossible and, without human evolution, all aesthetic and narrative experimentations in fictional texts cannot exist, since fictional texts, like fantasies, thrillers, detectives, adventures, and even the most serious forms of fictional techniques like stream of consciousness are the productive values of their respective social and material contexts. In either case, the dynamics of powerful ideologies, in the narrative and aesthetic structures of these fictional texts cannot be ignored. It is the politics of grammar and ideologically established archetypes in human un(conscious) or, at narrative level, of human syntax that, according to deconstruction theory, allow the free play [of] language (Derrida, 1997, p. 7) gimmicks in cultural and fictional texts. Taking the patriarchal advantage of this play in human language, the popular authors re-determine, according to the existing meanings in contexts, the position of a person, especially a female as an object in the syntax of their popularly written fictional text. Conversely, this narrative attitude openly problematizes the ontology of literature and art, in contemporary debates on literary and fictional texts.

The significant query, with reference to the literary interpretations, lies in the affordability of the impressionistic reading of a fictional text like dastan in the literary age after the advent of deconstructionist and poststructuralist questions on ideology, narrative, identity, gender, sexuality, desire, gaze, power, race, colour, and language binaries, etc. Up to liberal humanism and structuralism, the explanation of a text sufficiently worked for literary criticism, but, after poststructuralism, the entire culture of criticism became different, because the explanation of a literary text denotes the analysis through asking "how" whereas, its interpretation implies the question "why" (Macherey, 1978, p. 75). It means that, in academics, the hermeneutics 
of literary interpretations changed with the dawn of post-structuralist theoretical frameworks. The shift from "how" (how a literary text is composed) to "why" it has been composed and why (such a narrative discourse has been patterned) marks the interpretive immediacy of literary criticism.

This paradigm shift in critical debates questions the ontology of a fictional text, according to which, a seriously written literary text carries its meaningful weightage in resisting the hegemonic practices in societies. However, ironically, the syntax of popular fictional texts, instead of liberating the weaker character, the object, from play of structurally patronized and ideologically patterned language, proves to be the re-incarnation of traditional practices. Conversely, in this type of creative process, the objects of desire, the female characters, are imagined politically, structurally channelized, and ideologically recycled for the gratification of public taste. Declaring a fictional text like dastan an ideological exception ${ }^{4}$ signifies the lack of dialectics in existing criticism, particularly in Urdu language, because the dastan fictional tradition, despite its aesthetic exuberance, is a rich repertoire of cultural secrets and consequential factors that institutionalize narrative structures in the subcontinent.

Recent developments on the political kinship between narrative and power investigate the factors behind the supposedly untouchable formulations of patriarchal structures. The age-old mystified philosophy of imaginative or creative innocence in literature has been questioned through poststructuralist, feminist, postcolonial, and Marxist studies. Although the Feminist critics and scholars have questioned the very patriarchal constituents that determine the female position in popular western discursive practices, there is still an unquestioned cultural space in the subcontinent where the politicization of binary relationships between a dominant male hero and his object, the female character in the fictional texts like dastan narratives, needs to be debated and analysed.

It is with reference to the critical investigation of this traditionally established fictional politics in grand narratives of dastan that this research is being carried out. The tributary nature of criticism on dastan, written in Urdu language, has not been, so far, successful in accepting western tools of analysis. The reason for this indifference is, of course, the historical experience of IndoIslamic civilization in British Raj that made the sanctity of local cultural texts irrelevant. The modes of modernization were more interested in projecting reformative novels in Hindustan than in epic narratives like dastan. Culturally, the urbanized velocity was another factor in colonial India which encouraged short narratives and pushed the dastan narratives on margins. In addition to that, after partition of 1947, the literary attitude towards dastan has been more appreciative and less critical in nature. Nevertheless, despite this epistemological indifference between the East and West, the ontological significance of critical debates on desire, sexuality and objectification of female folk in fictional texts, whether they belong to the East or West, cannot be ruled out in any part of this world. Of much significance to know is the regressively imaginative perception of popular writers that, from feudalism to modern 
modes of capitalism, have failed to execute an egalitarian philosophy in fictional discourses.

A critical look at the previous and contemporary scholarship would be instructive to situate and contextualize this study. The significant book on the relationship between literary texts and cultural politics, Literature and the Political Imagination, edited by Baumeister and Horton (1996), includes some important essays presented in the Conference held at the University of York in 1993. In her book Man Made Language, Dale Spender (1980) illustrates, with a broader perspective, the power-monger linguistic relationship with patriarchy. Like other untraditional rationalists like Foucault-who has explained the formative pattern of truth in his words: "what is true depends on who controls the discourses" (Selden et al, 2005) —, "discourses are constituted in history and society what is included as truth, access to that truth, who may determine it, all depend on relation of power in institutions." (Talbot, 2010, p. 119). Talbot further notes, as Foucault argues, "that dominant members of institutions maintain control through discourses by creating order; that is, by being the ones who make boundaries and categories." (p.119). Spender (1980) has contributed her insightful study in setting the human language free from the concept 'natural,' the metanarratively constructed concept of language.

On the politics of masculine imagination, the renowned feminist Irigaray (1984) has, through deconstructing the epistemologically and teleologically constructed notions and images about woman, consolidated her feminist reaction in her works, especially Speculum of the Other Woman. The word 'speculum' in this phrase signifies, symbolically, a mode of "specularization" or "a journey of interiority" undertook "through a concave mirror" which dismantles the age-old reductionist behaviour much popularized in psychoanalytical and philosophical discourses (Bolton, 2008). It also indicates the nature and value of the operating lens or the device through which some body is scrutinized. Her works speak against the substratum or the biased practices of constructing the female image as an object in western metaphysics in particular and in male-oriented discursive practices, in general (Whitford, 1991).

In chapter "The Second Wave of Feminism", Selden, Widdowson, \& Brooker (2005) have explained how the feminist voice of De Beauvoir rationalizes the socio-psychological factors that ultimately result into a consequential objectification of women. The seminal book by Millet (200o), with a significant title Sexual Politics, is of historical importance and highlights patriarchal politics in cultural and literary texts. At subtext level, Cixous' Stigma (2005) is a profound reaction against the personification of patriarchal desires. Similarly, The Oxford Handbook of Gender and Politics (2013), through embedding textual and sexual relations, critically dissects the intellectually imbalanced male-female kinship in social structures. In a nutshell, from Simone De Beauvoir to Marry Eagleton, or from the First Wave to the current feminist scenario, the chief concern of these feminist writers has been the intuitive, cognitive cultural, textual and linguistic structures and patterns that manifest traditional partiality in embodying women in general, and 
(re)locating and (fore)grounding the voice and body of female characters in literary texts, in particular.

Apart from feminist debates, notable research has been carried out on objectification theory with reference to commercialization and commodification of female bodies in media. In the field of psychology, much thought-provoking discussion is available on the drastic psychological effects of women's objectification. According to research on sexual objectification, Fredrickson, and Roberts (1997) define the theory of objectification as "the appraisal of women in terms of their bodies or collection of body parts and the subsequent view of these body parts as objects for utilization." (Civile and Obhi, 2015, p. 1) have further experimented this theory in their research on sexualisation of men and women in media. In the book Body Work: Objects of Desire in Modern Narrative, Brooks (1993) has explained the relationship of female body with narratives and, by highlighting factors behind the reductionist thought patterns in modern narrative, he has psychoanalytically analysed textual and narrative attitudes against female bodies. Gladstein's (2004) research work, "Masculine Sexuality and the Objectification of Women: Steinbeck's Perspective," on the fictional world of Steinbeck has been considered a misogynist attitude against women, for Steinbeck's fictions commodify women through his myopic gaze. On Greek mythical and tragic characters, Heslin (2018) has debated the element of female objectification that shows how masculine gaze objectifies women in Grecian mytho-political structures.

\section{Objectification of Female Characters in Hoshruba, the Land and the Tilism}

With reference to the relationship between male gaze and female body, the dastan Hoshruba, the Land and the Tilism offers a long and objectified chain of events and female characters that, besides contextualizing politics of desire, present women as subserviently obedient to the commands or advances of chivalrous heroes. Barely victim to the male gaze and desire, the women characters in Hoshruba, the Land and the Tilism enjoy only ideological freedom their authors have bestowed upon them. There are, in this book, plenty of instances where the writer himself and his heroes are seen giving vent to their passionate desires to behold and fix the female bodies with utmost piquancy. In the subject-object relationship, the female characters have been syntactically objectified. For instance, in the very first episode of this dastan, the character of Princess Tasveer has been delineated with the multifarious colours of male desire to objectify the female body. The entire cluster of adjectives employed in this narrative discourse politically marks the identity of female bodies as objects of male desire potentially charged with temptation and seduction: "Coming his way was a party of coquettish girls as beautiful and lovely as the moon, and as stately as the sun in the heavens" (Farooqi, p. 12). It is also through the omnisciently patriarchal voice of the narrator that the implied beholder is seen copiously contriving poetic phrases like "nights of desires" 
They were of ages between fifteen and sixteen years

Familiar to the pangs of adolescence and nights of desires. (p. 12, italics original)

To execute the 'materialization of desire for an object that is not available in the society, the narrative voice, therefore, 'through fantasy', sensualizes his narrative discourse. Correspondingly, the adjective "coquettish" has been used with nouns "girls" which signifies the patriarchal right to identify women through politically motivated linguistic constituents. This is how the narrator, hero, the reader experience phallogocentric pleasure, ${ }^{5}$ the male desired jouissance (Bruanstein, 2003, p. 106), as we see the characters of these young girls, in Hoshruba, are loaded with seductively promising similes:

Between them was a princess whose beauty was the moon's envoy. She was the gazelle of the desert of beauty and a prancing peacock of the forest of splendour. She walked with her hand placed on the shoulder of one of her attendants,

Like the rose in a cluster of nightingales, the supreme lord Like the moon among stars, the lantern of heavens

and was outfitted in a fine costume and jewellery enchased with gems. Absorbed in the sights of the wilderness, she stepped with a graceful and haughty air (p. 12, italics original).

Controlling the gaze, the omniscient narrator is not only depicting the beauty of the princess through male gaze but also fixing her identity as a sex object to be desired. Formalistically and stylistically there is a harmonious blend of description and narration in the entire text of Hoshruba, but the syntactically semantic value of the text relies on the signification associated with textual desire of dastan. Seen through the textually politicized relationships, the signification negates conventional meanings. Underneath textual and narrative patterns in dastan, there exist layers of sexual politics through which the female characters hardly escape established norms. It has to be decoded by the critical tradition which is not simplistic in its philosophical essence. In addition to that, the romantic relationship between princess Tasveer and prince Badiuz Zaman foregrounds the ideological identity of the princess not as 'other' but 'a woman as ours.'

Some of these characters, exposed and trapped as others, are plotted in dastan in such a way as if they have been condemned to carry the burden of shame. The male gaze, in this episode, works befittingly with reference to the context of sexuality and objectification. Amar Ayyar, an instrumental character and the matchless master of tricks and supernatural powers, manoeuvres the situations shamelessly but successfully in favour of his Camp. He can go to any extent for the accomplishment of his mission. The narrative voice, in this section, blends proportionally with Amar Ayyar's pleasureseeking gaze:

Amar was regarding the whole scene from his hiding place when one of the princess's attendants felt the call of nature. She sat down to 
make water at some distance from Amar while her companions continued along their path. Amar reckoned that if he joined the princess's party he might find some clue that would help him locate the prince. He came out of the bush and threw his snare rope at the girl's answering the call of nature. When she raised the alarm, Amar stuffed her mouth with a trickster's ball and drugged her unconscious. He tied her to a tree and, putting a mirror before his face, began putting on coloured powder and trickster's lotions, changing his face to the girl's likeness. He took off her clothes and dressed himself in them. Leaving her tied there, Amr Ayyar rushed forward to join the party of attendants. (p. 13)

Barely defenceless against the mighty tricks of Amr Ayyar, the girl's awkward situation signifies her weak and vulnerable position in the organics of warfare. The pseudo phrase 'everything is fair in love and war' works intriguingly against the male enemies of Hamza Camp in general and females in particular. Equally, it echoes the socio-ethical crisis of a subjective attitude towards the kind of creative writing that aims at producing jouissance by twisting the veins of narrative ethos. This utter helplessness, in the hands of creator writers, can be equated with ugly contexts of Euripides' Medea who too faces anti-woman ugliness in an awkwardly polarized dramatic situation which has been debated by Christiane Sourvinou- Inwood (2104) in her truth-seeking essay "Myths in Images: Theseus and Medea as a Case Study." Sourvinou- Inwood claims "she is represented through a schema of the fleeing woman, the normal schema used to represent women (passive and innocent as well as wicked women) who are fleeing to escape a man who either is attacking them or wants to force his sexual attention on them, or otherwise threatens them." (p. 366)

Overwhelmed wholeheartedly, by the presumably seductive beauty of the princess, the authorial gaze ultimately results into an unappeasable urgency of desire to vanquish her beauty through the mechanics of objectification:
Ay desire, ay desire, the heart cried
I depart, I depart! Fortitude answered
The senses began to scatter and disperse
The heart held the standard of frenzy aloft
All sense of shame and dignity began to dissolve
And thus ensued a battle between the mind and heart. (p. 15, italics original)

These poetic lines become evident of the object fetishism. Obsessed with Princess Tasveer's beauty, the senses of the observer, the narrator, start craving for the 'embodiment' of unfulfilled desires. Psychoanalytically, the narrative unconscious becomes mouthpiece of those suppressed dreams which desire the 'sense of shame and dignity to dissolve'. In the same episode, the objectifying mechanics succeed in fixing the identity of the princess as a willing subject to the slavery of male desire and his sexuality: "With her one hand placed on the shoulder of her attendants, she came forward and smilingly 
put her hand in that of Prince Badiuz Zaman" (p. 29). Here she acts according to the same 'cultural, psychological and emotional conditioning of women' which has been focussed by feminists that, in their views, motivates her to accept her passive and objectified role in romance. She modestly said, "O Prince of auspicious fortune, you have honoured this unworthy slave by deigning to pay her a visit. It is my privilege and pride to receive you!" (Farooqi, p. 29). Consequently, the princess experiences metamorphosis - from a princess to a romantic slave - in her encounter with the commanding sexuality of the enemy camp and feels enslaved by the irresistibly romantic personality of the prince:

\section{Had I notice of your arrival \\ I would have grown the path with jasmine and roses I would not have allowed you to set foot on the ground With the broom of my eyelashes I would have cleaned your soles. (p. 29, italics original)}

It is an unconditional service pre-determined by the male sexuality in the subcontinent discursive practices that makes a princess willing to clean a male's soles with brooms of her eyelashes. In another romantic episode, the story of Prince Asad and Princess Mahjabeen Diamond-Robe, the authorial voice is seen harmonizing with the hasty desire of the prince who has encountered the fascinatingly seductive beauty of the princess Mahjabeen, the Diamond Robe in Hoshruba. The extensive use of adjective-loaded syntax lavishly delineates the objectified beauty of romantically enslaved princess:

When the prince looked up he saw a fairy-like beloved who made his heart the prey of flying arrows of her gaze. He saw a luminous sun of the sky of excellence and an inestimable pearl of the oyster of love. Her jet black locks made light of the subterranean darkness. The luminous and neat parting of her hair was the envy of the Milky Way. Her forehead was bright and high like the aspirations of the lofty minded. Her brows were shaped like bows. Her breasts were swollen like pomegranates. Her perfect chin looked a delicious apple. In her delicacy and charm she was like an elegantly cut ruby. Her gait was like the gait of the partridge dove, her speech sweet as a parrot's, her height akin to a box tree, her cheeks as beautiful as the moon. Her shapeliness robbed the beauties of the world of all their conceit and they hid from her. She was the sun of the sky of elegance and beauty. (p. 77)

Under the guise of romance, the discourse of sexual and textual politics highlighted by feminist writings mentioned in Literature Review becomes relevant in this research. Literary and fictional texts, like other modes of communication, also exploit language in their discourses. Language is an important mode of production that determines social and cultural relations, but on the basis of its contextual desires. In Hoshruba, the entire corpus of similes employed to paint the female characters becomes desirously motivated since its employment, through a detailed description, yields exploitation of female body parts. The above-mentioned scene appears to be harmonized with the sentimental comedy of courtly affairs where sentimentality is more telling 
and showing than the silent culture of honest relationships. Sentenced as the object of desire, the princess Mahjabeen too, like other female bodies, has been embodies through the rhetoric of hyperbole. The prince Asad has been captured and imprisoned by the forces of Afrasiyab and left to starve for a couple of days. Ironically the enemies have to lose a princess after each imprisonment of princes from Hamza Camp. It is again owing to the credulity of female folk in Hoshruba, the male characters of Hamza camp succeed in winnowing the hearts of the princesses of Afrasiyab camp. Consequently, bewitched by the alluring beauty of the princess, prince Asad falls headlong in love with Princess Mahjabeen Diamond-Robe:

The moment Prince Asad saw the light-incarnate beauty of Princess Mahjabeen Diamond-Robe he lost his heart and soul to her. The Princess smiled and accosted Asad, saying "O youth, the acts of stealing and thieving are most unbecoming. Tell me what you desire.” Regaled by her pearlscattering speech, the prince replied, "O gracious friend! O essence of my elegance! I was culpable of stealing food because I despaired for my life. I snatched food only after I had gone without several meals.” The princess said, "That you had been starving is obvious. But how can I help it?" you must find yourself a shelter and a source of food." The Prince replied, "O princess, I am thirsty for your comely sight and beg you the alms of your beauty." (p. 78)

Having begged the alms of Princess's beauty, the prince Asad faces an unpleasantly confusing situation. In Hoshruba, there are two kinds of women, the princesses and the sorceresses. Since most the princes are from supernormal structures, the princesses of Hoshruba are ideal matches for their lovers. On the other hand, Hoshruba is shown replete with nasty figures, the sorceresses. The princes have no interest in them as they are shown ignobly helpless because of their carnal and promiscuous desires:

I am old and no one ever gives me a second look. I should ask Afrasiyab to spare this prisoner's life and give him to me. This prisoner would be only too happy to have his life spared. I will take him with me and ravish him to my heart's content. Indeed, I must ravish him even now, and take him to my bed. (p. 79, italics original)

The lines show how an ideological construct, "the sorceress", has been delineated with politics of shame. Being a mad woman in the attic of promiscuous desires, this sorceress is humiliating her own self by giving vent to her carnality. The sorceresses, as they are considered eternally dammed creatures in religious doctrines, are bound to carry the burden of demonising proclivity and shame to catalyse the actions in plot. Evidently, the characters which are fantasied with colours of immodesty, like sorceresses of Hoshruba, they have to crave for certain transgression, and that is, with reference to IndoIslamic contexts, an act of subversion. Such characters in Hoshruba are characteristically humiliated and demonized for the sake of fantabulous quintessence in the entire chain of events. Like other princesses, the Princess Bahar of Spring-Quarter has also been created to mesmerize the senses of the readers. The word 'Bahar', in Persian and Urdu languages, means spring and 
obviously it is her spring like mesmerizing beauty that has been stripteased by the narrators in one of the sections on Bahar. As a neophyte in Amir Hamza camp, she renders her services honestly and proves to be faithfully victorious in moments of crisis. But, despite this depiction of gracefulness in her deeds, she remains an alluring object of desire in Hoshruba, the Land and the Tilism. A number of her body parts like tongue, mouth, lobe of ears, moles on neck and heart, swelling of chin, crease underneath, jasmine bosom, dainty walk, have been poetically painted and objectified with utmost covetous adjectives and similes. It is through the politics of aesthetics and fantasy that the narrator personifies a female body for the sexual pleasure of the audience. Passionately rhapsodized, the expression of next lines discloses the secrets of her body parts that pledge utmost pleasure in dastan narrative:

Such were her shoulders, arms, wrists and hands that

The worshippers of beloveds would swear to them their life's allegiance Had the connoisseur of beauty regarded the fine sheen,

\author{
"Because her bosom is clear as the mirror \\ It reflects the pupils of her eyes" they have exclaimed \\ When she dewed it smelled of rose essence \\ Before the refulgence of her stomach the moon hid its face \\ The shining navel of that inestimable pearl \\ Was like the face of Venice on the face of Earth \\ Like the line of sight is hidden in the eyes \\ Her waist existed and yet it did not
}

Even the glance of imagination could find on them no purchase

Why her shank should not rival the light of Tur

The soles her feet rivalled the cheeks of houris. (p. 184, italics original)

\title{
Conclusion
}

The dastan Hoshruba, the Land and the Tilism is an epic romance that includes increasingly interesting narrative events like thrills, adventures, trick and trap, flirt, loot, skirmishes, magic, sorcery, battles, romances and, above all, consequential objectification of female characters. Contrived at the peak of imagination, the narrative discourse of dastan evidently reflects an organized fantasy with conspicuous patterns of cultural and, ultimately, the patriarchal politics. Strongly conditioned with the masculine actions of the chivalrous heroes, the fantasy itself proves to be instrumentalized through popular narratives. In fantasizing the actions carried out by the chivalrous heroes who are fighting against the transgressors and the practitioners of black magic or the prohibited works of enchantment, the narrators bestow boundless masculine powers upon Muslim heroes. Hoshruba, being the land of tilism and enchantment, turns out to be a battlefield for conflicting desires.

That is the reason the narrative desire of the story tellers entails decisive episodes or events of sequence and consequence in narrative structures. The narrators of dastan obviously follow the age-old narrative 
values they learnt from their predecessors in their cultural contexts. Practicing traditional modes of narration, they would never narrate and depict anything beyond their cultural referentiality. It is because of this schematization of binary relationships in their historical structures that these writers materialize the settings, plots, and actions of their stories in accordance with structural truths of their society. Women, being the objects of their narrative desire, follow the age-old schematized plot of these stories and, hence, stay helplessly exposed and vulnerable to the dominant advances of heroes even in obnoxious settings. Out of plethora of instances, I have incorporated a couple of examples where the art of female characterization becomes ideologically victim to textual and sexual politics. In the entire narration, the narrative gaze is controlled by the authors, the narrators of dastan, that affirms Michael Foucault's thesis on the kinship between power and discourse. It is through this control that the narrators celebrate a free narrative space for desired textual and sexual binaries, kinships, classifications and hierarchies. There is a systemized coordination between the politics of desire and narrative discourse of Hoshruba coupled with the politics of culture in such a sophisticated way that not a single princess from Hamza's Camp has been depicted in the entire episodes of Hoshruba: the Land and the Tilism, (Book 1), whereas almost hundreds of sorceresses and princesses from Afrasiyab Camp are gazed at and objectified through an ideological and patriarchal lens, as long as their narratives desire.

\section{Endnotes}

${ }^{1}$ Musharraf Ali Farooqi, a Pakistani-Canadian writer translated the 19th century dastango Muhammad Hussain Jah's dastan into English which was published in 2009. He has translated one third of the first volume and schematizes this project in these words: "Tilism-e Hoshruba was published in Urdu in eight large volumes totalling over eight thousand pages. If each of these volumes had been translated as a separate book, each English volume would have come to 1500 pages or more. I decided to divide each of the eight volumes into three, making twenty-four volumes in English." https://www.tor.com/2015/04/o8/hoshruba-introduction/

${ }^{2}$ The phrase, critical consciousness, in the beginning of the article, marks distinctly the significance of anti-impressionistic modes of expression and interpretation in Urdu literary criticism.

3 A much popular term in contemporary criticism associated with French cultural critics, Deleuze and Guattari's Anti-Oedipus: Capitalism and Schizophrenia

4 Owing to the presence of religious and historical themes of battles between virtue and vice and also because of the presence of some religious characters in dastan, the criticism in Urdu hesitates to analyse it through poststructuralist debates.

5 https://www.criticalimprov.com/index.php/csieci/article/view/845/1398

${ }^{6}$ I have adapted this from Sandra Gilbert and Susan Gubar. See Sandra Gilbert and Susan Gubar (1979), Mad Woman in the Attic: The Woman Writer and the Nineteenth Century Literary Imagination, New Haven: Yale University Press.

\section{References}


NUML Journal of Critical Inquiry Vol 17 (II) December, 2019 ISSN 2222-5706

Baumeister, A., \& Horton, J. (1996). Literature and the political imagination. New York: Routledge.

Bolten, L, (2008). But what if the object started to speak? : The representation of female male consciousness on screen. In L. Irigaray and M. Green (eds.), Luce Irigaray: teaching. London: Continuum.

Braunstein, A. (2003). Desire and Jouissance in teachings of Lacan. In J.M. Rabate (ed.), The Cambridge Companion to Lacan. London: Cambridge University Press.

Brooks, P. (1984). Narrative desire. In Psychopoetics, Vol.18. No. 3. Pp.312327. Penn State University. Retrieved from

https://www.jstor.org/stable/42946134?seq=1\#metadata_info_tab_contents

Brooks, P. (1993). Body work: Objects of desire in modern narrative.

Massachusetts: Harvard University Press.

Cavallaro, D. (2007). Critical and cultural theory: Thematic variations. London: The Athlon Press.

Civile, C., \& Obhi, S. (2015). Power, objectification, and recognition of sexualized women and men, Psychology of Women Quarterly, pp. 1-14.

Cixous, H. (2005). Stigma. New York: Routledge.

Derrida, J. (1997). Of grammatology: The John Hopkins University Press.

Dreyfus, H. L., \& Rabinow, P. (2014). Michel Foucault: Beyond structuralism and hermeneutics. New York: Routledge.

Edmunds, L. (Ed.). (2014). Approaches to Greek myth: JHU Press.

Fredrickson, B., \& Roberts, T. (1997). Objectification theory: Toward understanding women's lived experience and mental health risks, Psychology of Women Quarterly. 21, 173-296.

Gladstein, R. (2004). Masculine sexuality and the objectification of women:

Steinbeck's perspective, The Steinbeck Review, Vol. 1, No 1, 119-123.

Greimas, A. (1983). Structural Semantics: An attempt at a method: University of Nebraska Press.

Heslin, p. (2018). Propertius, Greek myth and Virgil: Rivalry, allegory, and polemic: Oxford University Press.

Inwood, C. S. (2014). Myths in images: Theseus, Medea as a case study. In Lowell Edmunds (ed.), Approaches to Greek myth. Baltimore: John Hopkins University Press.

Irigaray, L. (1984). Speculum of the other woman. Trans. Gillian C. Gill, New York: Ithaca

Jah, M. H. (2009). Hoshruba, the land and the tilism, book 1. Trans. Musharraf Ali Farooqi, India: Random House.

Joseph, E. (2006). Language and politics: Edinburgh University Press. 
NUML Journal of Critical Inquiry Vol 17 (II) December, 2019 ISSN 2222-5706

Lovatt, H. (2013). The epic gaze: Vision, gender and narrative in ancient epic: Cambridge University Press.

Macherey, p. (1978). A theory of literary production. Trans. Geoffrey Wall. London: Routledge and Kegan Paul.

McEniry, M. J., Peaslee, R. M., \& Weiner, R. G. (eds.). (2016). Marvel comics into film: Essays on adaptations since the 1940s. North Carolina: McFarland.

Millett, K. (200o). Sexual politics: University of Illinois Press.

Moi, T. (1985). Sexual /textual politics: Methuen.

Nadeem, F. (2017). Structuralism and dastan narratives: Axes of knowledge, desire and power in Hoshruba. Journal of contemporary poetics. Vol. 1, Issue 2. $74-92$.

Rush, M. (1992). Society and politics: An introduction to political sociology. New York: Routledge.

Schanoes, V. L. (2016). Fairy tales, myth, and psychoanalytic theory: Feminism and retelling the tale. New York: Routledge.

Schiebinger, L. L. (ed.). (200o). Feminism and the body. New York: Oxford University Press.

Selden, R. Widdowson, P. \& Brooker, P. (2005). A reader's guide to contemporary literary theory. $5^{\text {th }}$ ed. New York: Pearson Longman.

Spender, D. (1980). Man-made language. New York: Routledge.

Strysick, M. (1997). The end of community and the politics of grammar. The Journal of cultural critique, No 30, University of Minnesota Press, 195-215.

Retrieved on May 06, 2019, from

https://www.jstor.org/stable/pdf/1354504.pdf?refreqid=excelsior\%3A2ocdc27f d675bb247dc277 3cd13f557

Talbot, M. (2010). Language and gender. $2^{\text {nd }}$ edition, Cambridge: Polity Press.

Toffoletti, K. (2007). Transforming Superheroes. In Haslem, W., Ndalianis, A., \& Mackie, C. J. (eds.). Super/Heroes: From Hercules to Superman.

Washington, D C: New Academia Publishing, LLC.

Waylen, G., Celis, K., Kantola, J., \& Weldon, L. (Eds.). (2013). The Oxford handbook of gender and politics. Oxford:Oxford University Press.

Whitford, M. (1991). Irigaray's body symbolic. In Hypatia: Feminism and the body, Vol. No.6, No. 3, pp. 97-110, Wiley. Retrieved from https://www.jstor.org/stable/3809841?seq=1\#metadata info tab contents

Zubrzycki, J. (2018). Empire of enchantment: The story of Indian magic.

Oxford: Oxford University Press. 